\title{
Retinoic Acid Deficiency Impairs the Vestibular Function
}

\author{
Raymond Romand, ${ }^{1,2}$ Wojciech Krezel, ${ }^{1,2}$ Mathieu Beraneck, ${ }^{3}$ Laura Cammas, ${ }^{1,2}$ Valérie Fraulob, ${ }^{1,2}$ Nadia Messaddeq, \\ Pascal Kessler, ${ }^{1,2}$ Eri Hashino, ${ }^{4}$ and Pascal Dollé ${ }^{1,2}$ \\ ${ }^{1}$ IGBMC (Institut de Génétique et de Biologie Moléculaire et Cellulaire), BP 10142, Illkirch F-67404, France, and Inserm U964, CNRS, UMR 7104, Université \\ de Strasbourg, Strasbourg, France, ${ }^{2}$ Centre d'Etude de la Sensori Motricité, CNRS UMR 8194, Université Paris Descartes, Sorbonne Paris Cité, 75270 Paris, \\ France, ${ }^{3}$ Center of Sensorimotor Studies, CNRS, UMR 8194, University Paris Descartes, Sorbonne Paris City, F-75270 Paris, France, and ${ }^{4}$ Department of \\ Otolaryngology-Head and Neck Surgery and Stark Neurosciences Research Institute, Indiana University School of Medicine, Indianapolis, Indiana 46202
}

The retinaldehyde dehydrogenase 3 (Raldh3) gene encodes a major retinoic acid synthesizing enzyme and is highly expressed in the inner ear during embryogenesis. We found that mice deficient in Raldh3 bear severe impairment in vestibular functions. These mutant mice exhibited spontaneous circling/tilted behaviors and performed poorly in several vestibular-motor function tests. In addition, video-oculography revealed a complete loss of the maculo-ocular reflex and a significant reduction in the horizontal angular vestibulo-ocular reflex, indicating that detection of both linear acceleration and angular rotation were compromised in the mutants. Consistent with these behavioral and functional deficiencies, morphological anomalies, characterized by a smaller vestibular organ with thinner semicircular canals and a significant reduction in the number of otoconia in the saccule and the utricle, were consistently observed in the Raldh3 mutants. The loss of otoconia in the mutants may be attributed, at least in part, to significantly reduced expression of 0 top 1 , which encodes a protein known to be involved in calcium regulation in the otolithic organs. Our data thus reveal a previously unrecognized role of Raldh3 in structural and functional development of the vestibular end organs.

\section{Introduction}

Retinoic acid (RA), an active derivative of vitamin A, is a signaling molecule essential for a wide range of biological processes in vertebrates, including cell proliferation, differentiation, and morphogenesis. The final step in RA synthesis (oxidation of retinaldehyde to RA) is mediated by three members of the aldehyde dehydrogenase family, the retinaldehyde dehydrogenases (Raldhs) 1-3. Each Raldh exhibits a distinctive tissue distribution, substrate specificity, and enzymatic efficiency (Duester, 2000, 2008; Ross et al., 2000; Duester et al., 2003). Despite a significant body of information describing striking phenotypes in various organs of mice lacking one or more Raldhs (for review, see Niederreither and Dollé, 2008; Duester, 2008; Rhinn and Dollé, 2012), and despite all three enzymes being highly expressed in the inner ear during development (Niederreither et al., 1999, 2002; Wagner et al., 2002; Romand et al., 2004, 2006), available information on inner ear phenotypes resulting from suboptimal RA synthesis is sporadic and indirect. Seminal works by Niederreither et al. $(1999,2000)$ presented the first direct evidence that inactivation of Raldh2 in mouse em-

Received Sept. 28, 2012; revised Jan. 28, 2013; accepted Feb. 21, 2013.

Author contributions: R.R. designed research; R.R., W.K., M.B., L.C., V.F., N.M., and P.K. performed research; E.H. contributed unpublished reagents/analytic tools; R.R., W.K., M.B., and P.D. analyzed data; R.R., W.K., M.B., E.H., and P.D. wrote the paper.

This work was funded by grants from National Agency for Research, Foundation for Medical Research, and funding from National Center of Scientific Research, National Institute of Health and Medical Research, National Center of Space Studies, and University Hospitals of Strasbourg.

Correspondence should be addressed to Raymond Romand, IGBMC, 1 rue Laurent Fries, 67404 IIIkirch Cedex, France. E-mail: romand@igbmc.fr.

DOI:10.1523/JNEUROSCI.4618-12.2013

Copyright $\odot 2013$ the authors $\quad 0270-6474 / 13 / 335856-11 \$ 15.00 / 0$ bryos results in a dramatic reduction in the size of the otocyst, confirming the necessity of RA in normal inner ear development. Unfortunately, early lethality of Raldh $2^{-/-}$mice precluded additional analyses of later embryonic stages. An alternative approach of treating chick or rat embryos with excess RA revealed disrupted development of vestibular and, to a lesser extent, cochlear structures, as well as impaired vestibular motor functions (Choo et al., 1998; Coluccia et al., 2008). However, these results should be interpreted with caution because increasing the RA level globally in the embryo could have both direct and indirect effects on inner ear development. To clearly understand the role for Raldhs and, more generally, RA in structural and functional development of the inner ear, we focused in this study on Raldh3 and Raldh1, two major Raldhs expressed in the developing vestibular organs (Romand et al., 2006). We analyzed mutant mice deficient in Raldh1 or Raldh3, as well as those lacking Raldh 1 and Raldh3 in combination. With Raldh3 knock-out mice being lethal at birth, we assessed postnatal development by rescuing these mutants by stage-specific maternal RA supplementation. This approach was used previously to prevent the occurrence of nasal defects in Raldh $3^{-/-}$mice, allowing their survival (Dupé et al., 2003). These rescued Raldh $3^{-1-}$ mice exhibited a loss of the maculo-ocular reflex (MOR) and a dramatic reduction in the horizontal angular vestibulo-ocular reflex (aVOR), which were accompanied by corresponding anatomical abnormalities, including smaller semicircular canals and missing otoconia in the utricle and saccule. Moreover, we found that expression of Otopetrin1 (Otop1), essential for otoconia formation and $\mathrm{Ca}^{2+}$ regulation in the inner ear (Hurle et al., 2003; Kim et al., 2010), was dramatically downregulated in Raldh $3^{-/-}$mutants. 


\section{Materials and Methods}

\section{Mutant mice}

Generation of Raldh1 and Raldh3 null mutant mice has been described

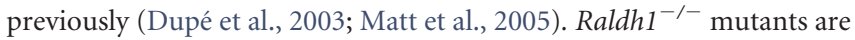

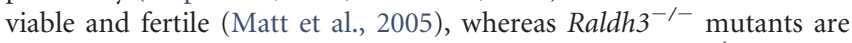

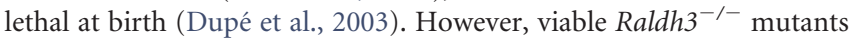
can be obtained by providing RA supplements to the pregnant mothers, which prevents the appearance of nasal defects in the mutants (Dupé et al., 2003). Here we used such prenatal treatment with all-trans-RA (MP Biomedicals) suspended in ethanol $(5 \mathrm{mg} / \mathrm{ml})$ and then mixed with $50 \mathrm{~g}$ of powdered food (R03 breeding diet from UAR) at a final concentration of $100 \mathrm{mg} / \mathrm{kg}$ food. The RA-containing food paste was provided to the pregnant mice ad libitum and replaced every day from E8.5 to E14.5. Generation of single or compound Raldh1;Raldh3 null mice was performed by mating adult mice heterozygous for both null mutations or Raldh $1^{-/-} ;$Raldh $3^{+/-}$mice. Mice were mated overnight, and animals having a vaginal plug at noon on the next day were considered as E0.5. All experimental procedures were performed in accordance with the guidelines by the European Union and approved by the institutional and regional ethical committees.

\section{Behavioral tests and video-oculography}

Animal housing. All mice were housed in individually ventilated cages (type "MICE"; Charles River) with a $12 \mathrm{~h}$ light/dark cycle (lights on from 7:00 A.M. to 7:00 P.M.). Food and water were freely available to the animals. Experimental cohorts of $n_{\text {control }}=12$ (including six wild-type, one Raldh $1^{+/-}$, two Raldh $3^{+/-}$, and three Raldh ${ }^{+/-} ;$Raldh $3^{+/-}$mice, which were not different among each other in all tested parameters and thus their data were pooled), $n_{\text {Raldh } 1-/-}=11, n_{\text {Raldh } 3-/-}=7$, and $n_{\text {Raldh1-/-;Raldh3-/- }}=7$ were constituted from male and female mice, with which behavioral tests were performed between 12 and 20 weeks of age. With the exception of the open-field test and video-oculography, which were performed with a dedicated group of animals (see below and Results), all animals were tested in a battery of behavioral tests. The tests were performed sequentially in the order described below, with 1-5 d intervals between each test.

Circling and head-tilting behavior. Circling and head-tilting behavior was evaluated in the home cage by removing the cage lid and observing spontaneous behavior of individual mice for $10 \mathrm{~min}$. Animals that turned around their own axis or exhibited running behavior in circles, the diameter of which did not exceed their body length, were identified, and their genotype was noted. Because head tilting appeared in circling animals, these behaviors were scored together.

Contact righting reflex. The test was performed as described previously as part of the SHIRPA (acronym of SmithKline Beecham, Harwell, Imperial College, Royal London Hospital, phenotype assessment) analysis (Mandillo et al., 2008). Briefly, mice were placed in a narrow, 3-cm-wide clear Plexiglas cylinder. The cylinder was held in a horizontal position and was rotated rapidly by $180^{\circ}$ to a position for an animal in a supine position. The time after which the mouse returned to its original prone position (dorsal part facing upward) was measured.

Beam walking. This paradigm was used to test motor coordination and balance in rodents (Carter et al., 2001). A 1-m-long wooden bar (2 cm in diameter) was elevated $50 \mathrm{~cm}$ above the ground with an obscure box placed at one of its end. During a habituation phase, each mouse was first placed in the box for $30 \mathrm{~s}$. After this period, the mouse was removed from the box and placed twice on the bar at increasing distances from the box and was allowed to reach the box and then hide in it for $30 \mathrm{~s}$. During the test, the mouse was placed on the bar on the opposite end of the box, and the time to reach the box and the number of paw slips were scored. The test was repeated three times at 5-10 min intervals.

Locomotor activity. The locomotor activity was tested simultaneously in five automated open fields $(44.3 \times 44.3 \times 16.8 \mathrm{~cm})$ made of polyvinyl chloride (PVC) with transparent walls and a black floor, covered with transparent PVC lids (Panlab). The open fields were placed in a room homogeneously illuminated at 150 lux. Each mouse was placed in the periphery of the open field and allowed to explore freely the apparatus for $30 \mathrm{~min}$, with the experimenter out of the animal's sight. Behavioral parameters were calculated automatically.
Swim test. The test was performed in a 1-m-long Plexiglas tank $(6 \mathrm{~cm}$ wide $\times 30 \mathrm{~cm}$ high) filled with water $(20 \mathrm{~cm}$ in depth $)$ at $21-23^{\circ} \mathrm{C}$. For habituation, animals were placed for $30 \mathrm{~s}$ on a platform located at one end of the tank, and subsequently they were gently placed into water at the opposite end of the tank. Normal swimming behavior was scored when an animal kept a horizontal body position, with its nose above the surface. Abnormal swimming was scored when the animal's position was vertical with nose pointing upward or, during a side swim, immobile floating, or underwater circling. Animals with underwater circling were removed from the tank immediately and were classified as non-swimmers.

Video-oculography. Eye-movement recordings were performed on a separate cohort of 22 mice, including $n_{\text {control }}=14\left(n_{\text {Raldh } 3+/+}=8\right.$; $n_{\text {Raldh } 3+/-}=6$ ) and $n_{\text {Raldh3-/- }}=8$. Surgical preparation and postoperative care for head implant surgery have been described previously (Beraneck and Cullen, 2007; Beraneck et al., 2012). Gas anesthesia was induced using isoflurane. A small custom-built head holder was cemented ( $\mathrm{C} \& \mathrm{~B}$ Metabond) to the skull just anterior to the lambda landmark (Stahl and Oommen, 2008). After the surgery, animals were isolated and closely surveyed for $48 \mathrm{~h}$. Buprenorphine $(0.05 \mathrm{mg} / \mathrm{kg})$ was provided for postoperative analgesia and care was taken to avoid hypothermia and dehydration.

The experimental setup, apparatus, method of data acquisition, and analysis used to record eye movements were similar to those described previously (Beraneck et al., 2012). Mice were head fixed at a $\sim 30^{\circ}$ nosedown position to align the horizontal canals in the yaw plane (Calabrese and Hullar, 2006; Oomen and Stahl, 2008). Animals were placed in a custom-built Plexiglas tube secured on the superstructure of a vestibular stimulator. Eye movements were recorded using an infrared video system (ETL-200; ISCAN). For the stimulation protocol, the light intensity in the experimental room was of 350 lux (Luxmeter, Lux-1337 Iso-tech). The "light" condition was used to record spontaneous eye movements and for the optokinetic reflex (OKR). For tests performed in the dark, including the spontaneous eye movements, sinusoidal horizontal VOR, horizontal steps, and off-vertical axis rotation, all light sources were turned off except for a computer screen. The turntable was further surrounded with a closed box to isolate the animal from remaining light. The "dark" condition inside the box was measured as $<0.02$ lux. The following tests were performed. (1) Ten minutes before the start of an experiment, regardless of the light or dark condition, $2 \%$ pilocarpine (Laboratoire Chauvin) was applied to both eyes of the animal to keep its pupil size constant (van Alphen et al., 2010). (2) Spontaneous eye movements were first recorded in the absence of external stimulation with light (350 lux) and then in the dark ( $<0.02$ lux). (3) Horizontal VOR in the dark was tested during sinusoidal rotation around the vertical axis (frequencies, 0.2 and $1 \mathrm{~Hz}$; peak velocity, 50\%; accelerations, 80 and $2000^{\circ} / \mathrm{s}^{2}$ ). The semicircular canal time constant of the VOR was measured in response to angular rotation (constant velocity, $50^{\circ} \%$; acceleration, $500 \% \mathrm{~s}^{2}$; three complete cycles) performed in the clockwise and then counterclockwise direction. (4) Optokinetic full-field stimulation was performed with light by rotating the animal without the surrounding closed box (constant velocity, $5 \%$; three complete cycles) in the clockwise and then counterclockwise direction. In the mouse, optokinetic speed tuning curve for the eye-movement responses demonstrated peak gains at rotating velocities in the range of $0-5 \%$ (Stahl , 2004; Beraneck and Cullen, 2007, their Fig. 8 A).

Once the yaw testing was completed, the table was tilted $15^{\circ}$ offvertical axis with the mouse in a nose-down position. Off-vertical axis rotation responses were tested in the dark (constant velocity, 50\% $; 10$ complete cycles) in randomized clockwise and counterclockwise directions.

Eye- and head-position signals were sampled at $1 \mathrm{kHz}$, digitally recorded (CED power1401 MkII; Cambridge Electronics Design) with the Spike 2 software and later exported into MATLAB (MathWorks) programming software for offline analysis. Analysis procedures were similar to those reported previously (VOR and off-vertical axis rotation: Beraneck et al., 2012; OKR: Chevallier et al., 2013). Semicircular canal time constants in response to velocity steps (tau) were extracted from the desaccaded horizontal slow-phase eye position. The eye position, $E H p(t)$, 
was fitted to the equation $E H p(t)=E H p_{\max } \times[1-\exp (-t /$ tau $)]$ using custom-made MATLAB routines based on the curve fitting toolbox "fit" function with a nonlinear least-square method.

Statistical analyses. To evaluate potential interactions between Raldh1 and Raldh 3 null mutations, two-way ANOVAs with Raldh1 and Raldh3 genotype as two independent variables and behavioral responses as dependent variables were performed. Post hoc statistical comparisons of

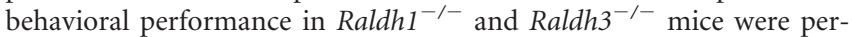
formed using the protected least significant difference test or Student's $t$ test for two-group comparisons. Post hoc test results are indicated in the corresponding figures together with the number of animals used for each experiment. Analyses of turning/tilted head behavior and swim ability were performed using the $\chi^{2}$ test. The Tukey's test was used for videooculography data.

\section{Histology and transmission electron microscopy}

Fetuses or adult mice after functional testing were decapitated, and their inner ear was rapidly removed and fixed by immersion in $2.5 \%$ paraformaldehyde and $2.5 \%$ glutaraldehyde in cacodylate buffer $(0.1 \mathrm{M}), \mathrm{pH} 7.2$, overnight at $4^{\circ} \mathrm{C}$. Inner ears at postnatal stages were decalcified in $10 \%$ EDTA, dehydrated, and washed in cacodylate buffer for $30 \mathrm{~min}$, followed by postfixation with $1 \%$ osmium tetroxide in $0.1 \mathrm{M}$ cacodylate buffer for $1 \mathrm{~h}$ at room temperature. The specimens were dehydrated through graded alcohol series and were embedded in Epon 812. Semithin serial sections were cut at $2.5 \mu \mathrm{m}$ (Leica ultracut UCT), stained with toluidine blue, and observed under a light microscope (Leica DMLB). Imaging was performed with a CoolSNAP digital camera and software. Ultrathin sections for electron microscopy were obtained from semithin sections reembedded in Epon and contrasted with uranyl acetate and lead citrate. Ultrathin sections were examined at $70 \mathrm{kV}$ with a Morgagni 268D electron microscope. Images were captured digitally by a Mega View III camera (Soft Imaging System) and processed with Adobe Photoshop software (Adobe Systems).

\section{In situ hybridization}

The heads of E18.5 fetuses were pealed and then fixed with 4\% paraformaldehyde in PBS at $4^{\circ} \mathrm{C}$ overnight. The samples were rinsed in PBS (1 h), cryoprotected in $20 \%$ sucrose solution in PBS overnight, and embedded in Cryomatrix (Shandon). The blocks were frozen on dry ice and stored at $-80^{\circ} \mathrm{C}$. Cryostat serial sections $(10 \mu \mathrm{m})$ were cut in the sagittal plane, mounted as parallel sets on SuperFrost Plus slides, and stored at $-80^{\circ} \mathrm{C}$ until use. In situ hybridization (ISH) was performed with digoxigenin-labeled probes as described previously (Chotteau-Lelièvre et al., 2006). Template DNAs were obtained from the EURExpress consortium (www.eurexpress.org; Diez-Roux et al., 2011) [Otoconin (Oc90), $\alpha$-Tectorin (Tecta), NADPH oxidase organizer (Noxo1), Otoancorin (Otoa), Otogelin (Otog), and Superoxide-generating NADPH Oxidase (Nox3)] or kindly provided by M. Petkovich (Queen's University, Kingston, Ontario, Canada) (Cyp26b1), D. M. Ornitz (Washington University, St. Louis, MO) (Otop1), A. McMahon (California Institute of Technology, Pasadena, CA) (Fgf3), G. R. Martin (University of California, San Fransisco, CA) (Fgf8), F. Perrin-Schmitt (Université de Strasbourg, Strasbourg, France) (Fgfr3), B. L. Hogan (Duke University, Durham, NC) (Bmp4), J. Epstein (University of Pennsylvania, Philadelphia, PA) (Shh), A. Simeone (SEMM European School of Molecular Medecine, Naples, Italy) (Otx1, Otx2), J. Briscoe (National Institute for Medical Research, London, United Kingdom) (Gli3), P. Gruss (Max Plank Institute for Biophysical Chemistry, Göttingen, Germany) (Pax2), J. Hébert (Albert Einstein College of Medecine, Bronx, NY) (Foxg1), T. Lufkin (Genome Institute of Singapore, Singapore) (Hmx2,Hmx3), G. Levi (Muséum National d'Histoire Naturelle, Paris, France) (Dlx5), P. Bouillet (The Walter and Eliza Hall Institute of Medical Research, Melbourne, Victoria, Australia) (Gbx2), and R. J. Bollag (Georgia Health Sciences University, Augusta, GA) (Tbx2).

\section{Immunohistochemistry}

For neurofilament immunostaining, E18.5 heads were fixed and cryosectioned as described above. After defrosting, the sections were dried at room temperature for $1 \mathrm{~h}$, washed in PBS, and then in PBS with $0.1 \%$ Triton X-100 (PBT). Antigen unmasking was performed in $0.01 \mathrm{M}$ so- dium citrate buffer at $\mathrm{pH} 6$ (three times for $5 \mathrm{~min}$ ) in a microwave oven $(1600 \mathrm{~W})$, and slides were cooled down for $30 \mathrm{~min}$ and rinsed in PBS. Nonspecific binding was blocked in PBT added with $10 \%$ heat-treated normal goat serum for $1 \mathrm{~h}$ at room temperature. The primary antibody (supernatant of densely grown hybridoma cells producing $2 \mathrm{H} 3$, a mouse monoclonal antibody against the $155.10^{3} M_{\mathrm{r}}$ neurofilament protein; Developmental Studies Hybridoma Bank, John Hopkins University) was added at a 1:1 dilution in the blocking solution and incubated overnight at $4^{\circ} \mathrm{C}$. All subsequent steps were performed at room temperature. After washing in PBT (three times for $5 \mathrm{~min}$ ), endogenous peroxidases were inactivated in water with $3 \% \mathrm{H}_{2} \mathrm{O}_{2}(5 \mathrm{~min})$. After washes in PBS and PBT, incubation with biotinylated goat anti-mouse secondary antibody and then with the avidin-biotin complex (ABC, Vectastain; Vector Laboratories) was performed. Histochemical detection of peroxidase activity was performed by using diaminobenzidine and $\mathrm{H}_{2} \mathrm{O}_{2}$ as substrates. After 3-4 min, the sections were rinsed two times in water, allowed to dry overnight, and coverslipped with Coverquick.

Three-dimensional computer reconstructions of vestibular organs Three-dimensional (3D) reconstructions of the inner ear were generated from $\sim 280$ serial sections of E18.5 wild-type and Raldh $3^{-1-}$ fetuses. Images of serial sections were captured with a light microscope (Leica DMLB) equipped with a CoolSNAP digital camera and software. Sections were first aligned to correct $x y$ misalignments using the "Linear Stack Alignment with SIFT" plugin of Stephan Saalfeld (Max Planck Institute of Molecular Cell Biology and Genetics, Dresden, Germany) available on Fiji (http://pacific.mpi-cbg.de/wiki/index.php/Fiji). Thereafter, 3D reconstructions were generated using Imaris (Bitplane). A volume rendering software (Amira from TGS) was used to visualize and rotate three-dimensional datasets. The surface of the dorsal semicircular canal cross-section was calculated with Fiji from 20 measurements obtained from three mutant and three control mice used for the 3D reconstructions. The statistical analysis of the obtained data was performed with the Student's $t$ test when the distribution was normal, and $p$ values were calculated for the comparison between control and mutant mice.

\section{Results}

\section{Behavioral analyses}

After maternal RA treatments to rescue the lethality of Raldh3 $3^{-/-}$ mutants (Dupé et al., 2003), the mutants could be easily identified in their home cages by repetitive clockwise or counterclockwise circling behaviors, which was accompanied by tilting of the head $\left(p<0.001, \chi^{2}=3.9\right.$; Fig. $\left.1 A\right)$. The Raldh $3^{-/-}$mice also displayed significant deficits in the $1 \mathrm{~m}$ swim test $\left(p<0.001, \chi^{2}=3.9\right)$; only one of seven mutants succeeded to reach the platform, whereas all remaining mutants failed the test, displaying underwater swimming with simultaneous circling around their body

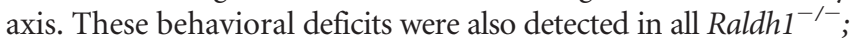
Raldh $^{-/-}$double-knock-out mice but were absent in control or Raldh $1^{-/-}$mice (Fig. 1B). Spontaneous circling behaviors and

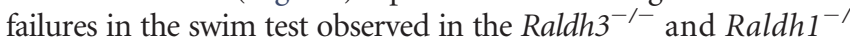
$-;$ Raldh $3^{-/-}$mice suggest dysfunctions in the vestibular system. This hypothesis was further reinforced by a significantly increased latency to turn in the righting contact reflex test in Raldh $3^{-/-}$and Raldh $1^{-/-} ;$Raldh $3^{-/-}$mice (Fig. $1 C$ ). In contrast, no increase in the latency was detected in Raldh $1^{-/-}$mice. It was apparent that the increased latency in the test was solely related to the Raldh3 genotype $\left(F_{(1,33)}=38.5, p<0.001\right)$, because no synergistic effect between the Raldh1 and Raldh3 null mutations was detected $\left(F_{(1,33)}=125\right.$, NS). Raldh3 null mutation was also predominant in generating deficits in the beam-walking test as evidenced by an increased latency to cross a $1 \mathrm{~m}$ beam $\left(F_{(1,29)}=41.7\right.$, $p<0.001$; Fig. $1 D)$, as well as an increased number of paw slips while moving on the beam $\left(F_{(1,29)}=41, p<0.001\right.$; Fig. $\left.1 E\right)$. Together, these behavioral results consistently point to the hypothesis that Raldh3, but not Raldh1, is required for proper development of vestibular functions. 
A

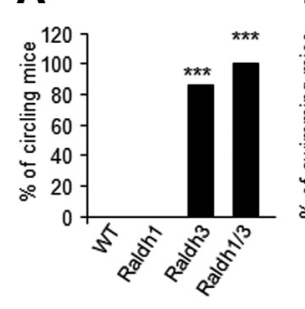

B

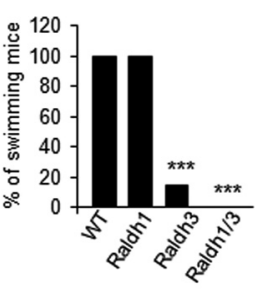

C
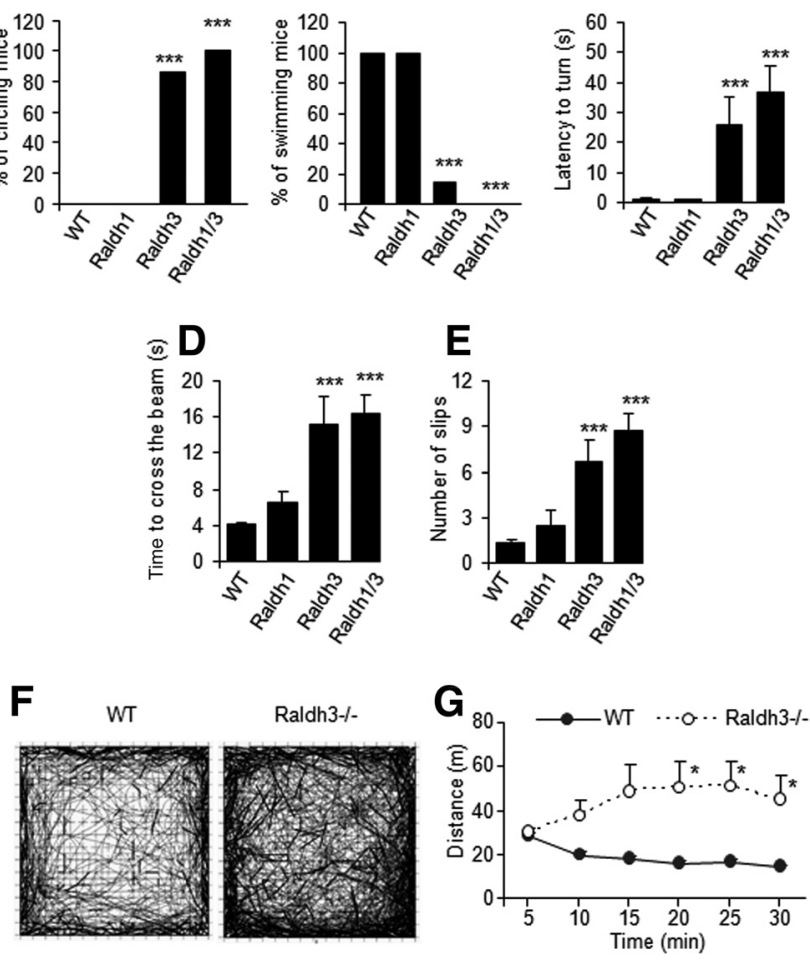

Figure 1. Behavioral deficits in Raldh3 and Raldh1;Raldh3 null mutant mice. A, Score of

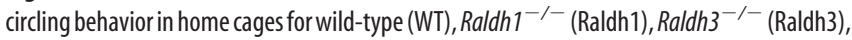
and Raldh $1^{-/-} ;$Raldh $3^{-/-}$double-null (Raldh1/3) mice. $\boldsymbol{B}$, The ability to swim was evaluated in a $1 \mathrm{~m}$ swim test as the animal's ability to reach the platform. $C$, Similar to the swim test, only Raldh3 and Raldh1/3 mice displayed significantly increased latencies until the animal turns in the righting contact reflex test. $\boldsymbol{D}, \boldsymbol{E}$, Both latency (time necessary to cross a 1-m-long beam; $\boldsymbol{D}$ ) and number of slips $(\boldsymbol{E})$ in the beam-walking test were significantly increased for the Raldh $3^{-1-}$ and Raldh $1^{-1-}$;Raldh $3^{-1-}$ mice. $F$, Examples of trace of the distance covered by wild-type (left) and Raldh $3^{-/-}$(right) mice in the open-field test. G, Modification of the locomotor activity over $30 \mathrm{~min}$ in the open-field test, for Raldh $3^{-/-}$mutants compared with wild-type littermates. ${ }^{*} p<0.05,{ }^{* * *} p<0.001$.

Vestibular functional deficiencies can potentially affect the performance in behavioral tests that depend on motor skills. To test this possibility, we performed the open-field test with four wild-type and five Raldh $3^{-/-}$littermate mice. The total distance of an animal's trajectory during $30 \mathrm{~min}$ of testing for Raldh $3^{-1-}$ mice $(261.5 \pm 54.9 \mathrm{~m})$ was twice as long as for wild-type controls $(114.7 \pm 3.2 \mathrm{~m} ; p<0.05)$, which was also evident on the trace of locomotor activities over this period (Fig. $1 F$ ). Such hyperactivity primarily attributable to circling behavior was not persistently observed during the 30 min testing period and evolved differently in Raldh $3^{-/-}$and wild-type mice, as evidenced by significant interactions between genotype $\times$ distance $\left(F_{(5,35)}=5.4, p<\right.$ $0.001)$. Most notably, the locomotor activity gradually increased throughout the testing period for Raldh $3^{-/-}$mice, whereas it declined over time for wild-type mice. During the last three 5 -min epochs, the locomotor activity of the mutants was significantly higher than that of wild-type mice (Fig. $1 G)(p<0.05)$.

\section{Vestibulo-ocular, macula-ocular, and OKR analyses}

Because behavioral tests are multifactorial, we took a direct approach and measured the VOR, a short-latency sensorimotor reflex. Using different vestibular stimulations, we aimed at identifying the origin of the motor deficits observed in Raldh $3^{-/-}$ mice, comparing the otolithic functions (MOR) tested during off-vertical axis rotation and the canal function (aVOR). The off-vertical axis rotation evokes nystagmic eye motion with the slow phase in the opposite direction of the stimulus, as reported previously (Fig. 2A; Beraneck et al., 2012). During the steadystate utricular-only response, $50 \%$ rotations in the counterclockwise direction evoked a mean gain bias of $0.2 \pm 0.03$ with a corresponding phase lag of $45.7 \pm 6.6^{\circ}$. The same test for Raldh $3^{-/-}$mice revealed a complete absence of utricular modulation (Fig. $2 B$ ); during the steady-state part of the stimulation, no consistent horizontal eye movements were observed (Fig. 2C; gain, $0.002 \pm 0.012$; phase lag, $33.5^{\circ} \pm 7.5 ; p<0.001$, Tukey's test). The absence of response was also observed in the CW direction. These results demonstrate a major impairment in the MOR and suggest possible abnormalities in the utricle. Sinusoidal rotations around the vertical axis in the dark evoked in control mice ( 0.2 and $1 \mathrm{~Hz}, 50^{\circ}$ s; Fig. 2D) typical stabilizing eye movements, as compensatory slow phases interrupted by quick-phases that re-center the eye in the orbit (Fig. 2D). In contrast, in Raldh $3^{-/-}$ mice (Fig. $2 E$ ), both the amplitude and timing of the aVOR were impaired ( $p<0.001$ at both tested frequencies, post hoc Tukey's test). Notably, a clear reduction in the amplitude of the horizontal slow-phase eye motion was observed in the majority (five of

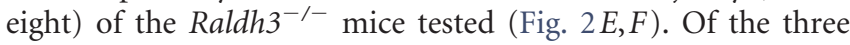
remaining mice, one had a clear asymmetry in the responses, and the two others showed defaults in the aVOR spatial tuning (data not shown). Collectively, all Raldh $3^{-/-}$exhibited qualitatively and quantitatively abnormal aVOR responses. To investigate whether the canal time constant was affected, mice were tested using horizontal constant velocity rotations $\left(50 \%\right.$; $500 \% \mathrm{~s}^{2}$ acceleration) performed in the dark. In control mice (nine mice; $n=$ 27 analyzed steps), yaw steps evoked nystagmic eye motion at the onset of rotation as several slow phases directed in the opposite direction of the rotation (Fig. $2 G$ ). A similar, inverted response was observed at stimulus offset. The mean eye movement produced during the nystagmic response was of $92.6 \pm 8.4^{\circ}$, with a canal time constant of $3.3 \pm 0.2 \mathrm{~s}$. In Raldh $3^{-1-}$ mice (six mice; $n=21$ analyzed steps), nystagmic responses were absent or greatly reduced (Fig. $2 H$ ). The compensatory responses consisted of reduced eye motion with a mean eye movement of $35.0 \pm 8.0^{\circ}$ and a canal time constant of $1.3 \pm 0.3 \mathrm{~s}$ (Fig. $2 I)(p<0.001$ compared with controls).

Moreover, in the absence of movement, a nystagmus and/or ocular instability was detected in all (eight of eight) Raldh3 $3^{-/-}$

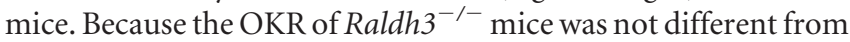
controls ( $5 \%$ stimulation; gains of $0.47 \pm 0.055$ and $0.49 \pm 0.16$, respectively; $p=0.864$ ), the observed nystagmus likely originates from vestibular impairment.

\section{Morphological defects in the vestibular organs of Raldh ${ }^{-/-}$ mice}

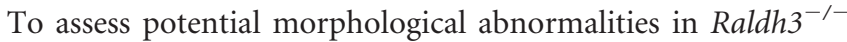
mutants, we first generated $3 \mathrm{D}$ reconstructions of the vestibular organs from serial histological sections of E18.5 wild-type and Raldh $3^{-/-}$mice. All five vestibular organs, including the three semicircular canals, the saccule, and the utricle, were present in both Raldh $3^{-/-}$and wild-type mice (Fig. 3). However, the diameter of all ducts, including the semicircular canals, the common crus, the scala media of the cochlear canal, and the endolymphatic sac, were notably smaller in mutants than wild-type controls, with the exception of the endolymphatic canal. The saccule was very small and the connection with the canal reuniens was shorter in the mutant ear (Fig. 3). The area size of the semicircular canal per cross-section in mutants $\left(809.0 \pm 63.9 \mu \mathrm{m}^{2}\right)$ was sig- 
nificantly smaller than in wild-type controls $\left(2868.4 \pm 156.3 \mu \mathrm{m}^{2}, p<0.0001, t\right.$ test). No statistically significant difference was detected between the left and right semicircular canals in both mutants and controls $(p>0.3)$.

More detailed analyses of vestibular

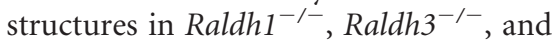
Raldh $1^{-/-} ;$Raldh $^{-/-}$mutants, at both prenatal and postnatal stages (as summarized in Table 1), were performed using both light and transmission electron microscopy. The three cristae and their associated semicircular canals are responsible for detecting angular head movements. At the basis of each semicircular canal is a structure called the ampulla, which contains a crista comprising two types of sensory hair cells and underlying supporting cells. Sensory hair cells are topped with stereocilia, one kinocilia and a gelatinous substance over the cilia called the cupula (Fig. 4). Semicircular canals are responsible for angular acceleration detection (Adrian, 1943; Goldberg and Fernandez, 1971; Angelaki et al., 1995). A normal morphology of the three cristae was observed in both wild-type and mutant mice (Fig. 4; Table 1).

The other components of the vestibular peripheral system are the utricle and the saccule, both of which are embedded in the bony structure of the temporal bone. In these otolithic organs, sensory hair cells in the neuroepithelial maculae detect gravity and linear acceleration. Above the maculae, embedded in a layer of acellular matrices, lie the otoconia, crystalline structures that act as inertial masses subject to the effects of gravity and shifting in response to linear acceleration (Adrian, 1943; Fernández et al., 1972; Fernández and Goldberg, 1976; Lim, 1984; Angelaki et al., 1995; Jones et al., 2005).

According to previous observations, the formation of otoconia in the mouse starts as early as E14 (Lyon, 1955; Lim, 1984), with a maximum growth between E15 and E16 (Anniko, 1980; Erway et al., 1986; Hughes et al., 2006). Outside the neuroepithelium, the endolymphatic region of the utricle and the saccule is lined by a membrane called the membrane limitans comprising a squamous epithelium of ectodermal origin and a thin connective tissue layer of mesodermal origin, these two cellular layers being separated by a basal membrane (Fig. 5A) (Iurato, 1967; Lindeman, 1969). As a result, the utricle and the saccule are normally separated by two membrane limitans, one lining the utricle and another the saccule.

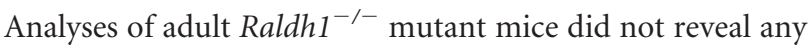
morphological differences in the utricle and the saccule when compared with those of wild-type mice (data not shown). How-

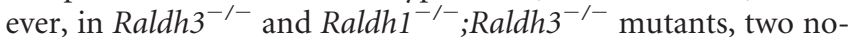
table differences were observed at various ages, including E18.5, P10, and adulthood (Table 1). First, there were striking morphological differences in the utricle and the saccule. A gigantic chamber between the utricle and the saccule at the endolymphatic level was commonly observed in Raldh $3^{-1-}$ mutants at E18.5 (Table 1, No separation). This was apparently caused by the absence of membranous separation between the utricle and the saccule (Fig.
$6 A, B)$. In several instances, the sensory epithelia of the utricle and saccule were very close or without a clear separation, generating a fused utriculo-saccular chamber (Fig. 6B). Some degrees of variations from this most extreme case were also observed. For example, a separation was present between the utricle and the saccule but made only by the membrane limitans from the utricle (mouse 50) (Fig. $6 F$ ). In some mutants at various stages (E18.5 and postnatal), we found that the membrane limitans, which usually lines the top of the saccule, had collapsed on the macular sensory epithelium, causing the fusion of the saccule and the utricle (Figs. 5C, 6D, F,I). The collapse of the membrane limitans was never observed in the utricular chamber, compatible with the presence of free-standing stereocilia (Fig. $5 E, F$ ). When the membrane limitans lining the saccule had not collapsed on the macula sacculi, hair cells with intact stereocilia were observed in Raldh $3^{--}$mutants at E18.5 onward, as was seen in control mice (Fig. 5F; Table 1).

A second (and the most profound) difference between Raldh $3^{-/-}$mutants and controls was the absence, or a significant reduction, in the number of otoconia in the utricle and the saccule. Consistent with published data indicating that otoconial formation begins at approximately E14.5 in the mouse (Lyon, 1955; Lim, 1984), no otoconia were observed in any of serial semithin sections at E14.5, in either Raldh $3^{-/-}$mutants or control mice. Our light-microscopic observations were further confirmed by transmission electron microscopy performed on one mutant (mouse 161) and one control (mouse 167; Table 1), in which no otoconia were observed at this stage in areas above the sensory epithelia (data not shown). At E18.5, in control (mice 200 and 223) or Raldh $1^{-1-} ;$ Raldh $^{+/+}$(mouse 24) mice, otoconia were visible and were located over the otoconial membrane in which stereocilia were embedded (Figs. $5 B, 6 A, E$ ). In contrast, in 


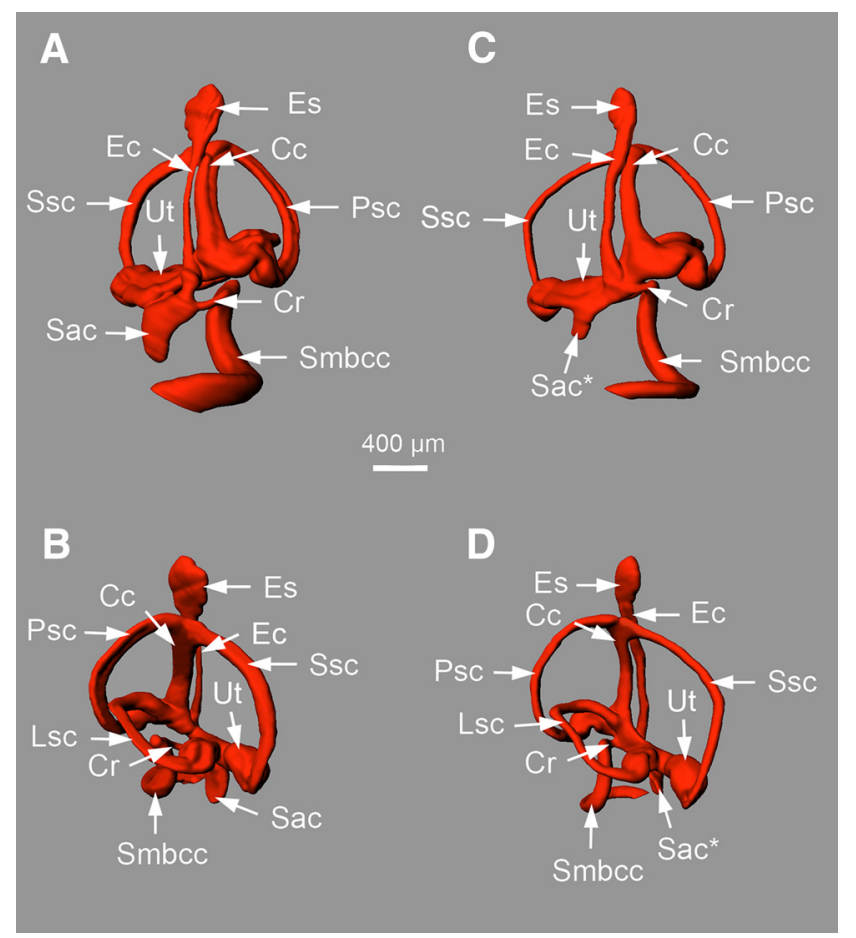

Figure 3. 3D computer reconstructions of E18.5 vestibular organs. $\boldsymbol{A}, \boldsymbol{C}$, Reconstructions of the vestibular structures of an E18.5 control ( $R$ aldh $3^{+/+}$) mouse $(\boldsymbol{A})$ and an Raldh $3^{-/-}$mutant (C) $B, D$, Alternative views of the vestibular structures rotated $180^{\circ}$ from $A$ and $C$, respectively. The semicircular canals and the common crus, except the endolymphatic canal, in the mutant mouse are thinner than those in the control mouse. In addition, the endolymphatic sac and the saccule are much smaller than in control mouse. Cc, Common crus; $\mathrm{Cr}$, canal reuniens; Ec, endolymphatic canal; Es, endolymphatic sac; Lsc, lateral semicircular canal; Psc, posterior semicircular canal; Sac, saccule; Sac*, hypoplastic saccule; Ssc, superior semicircular canal; Smbcc, scala media of the basal cochlear canal; Ut, utricle.

Raldh $^{-1-}$ mutants (mice 29, 222, and 385), otoconia were very often absent, although hair cells stereocilia and the otoconial membrane were present (Fig. $5 F, 6 B$ ). Interestingly, the presence of a single Raldh 3 functional allele (in Raldh $1^{+/+} ;$Raldh $^{+/-}$mutants) appeared to be sufficient for the formation of normal otoconia (mice 1917 and 1944; Table 1). Nonetheless, not all of Raldh $3^{-1-}$ mutants exhibited this striking phenotype: of the 13 mutants analyzed on serial semithin sections from E18.5 up to 6 months postnatally, only six had a small number of otoconia, including a single otoconium mostly confined to a small region of the macula utriculi (Fig. 6C,G,J; Table 1).

Interestingly, in one Raldh ${ }^{-1-}$ mouse (mouse 50), a single, giant otoconium reminiscent of a fish otolith was identified in the utriculi of the right ear at P10 (Table 1; Fig. 6F, G). On the macula sacculi of an E18.5 Raldh3 ${ }^{-/-}$mutant (mouse 29), some otoconia appeared to be trapped between the collapsed saccular membrane and the macula sacculi (Fig. 6D). Of the three rescued Raldh $3^{-/-}$mutants in which both left and right inner ears were examined, two showed differences in the phenotype between the two ears (mice 29 and 50; Table 1). In mouse 29, one ear had a small number of otoconia in a restricted region of both the utricle and the saccule (Fig. $6 \mathrm{C}$ ), and the other ear had some otoconia trapped between the collapsed saccular membrane and the macula sacculi (Fig. 6D).

\section{Gene expression analysis in the vestibular organs of Raldh3 $3^{-/-}$ mice}

We first examined, using ISH, expression of the following genes known to be expressed in the vestibular organs during develop- ment (Chatterjee et al., 2010), with some being regulated by RA (Romand, 2003; Delacroix et al., 2010): Bmp4, Dlx5, Fgf3, Fgf8, Fgfr3, Foxg1, Hmx2, Hmx3, Gbx2, Gli3, Gata2, Otx1, Otx2, Pax2, $S h h$, and $T b \times 2$. We found no differences in the expression pattern of any of these genes in the vestibular organs between Raldh3 $3^{-/-}$ mutants and age-matched controls at E18.5 (data not shown). In search for other genes whose expression might be modified by inactivation of Raldh3, we analyzed Cyp26b1 (Fig. 7D) and additional genes known to be involved in the development of the otoconial membrane and otoconia (Hughes et al., 2006; Lundberg et al., 2006). These included Tecta, Oc90, Otop1, Otog, Otoa, and Noxo1. Of all genes tested, only expression of Otop 1 was markedly downregulated in Raldh $3^{-1-}$ mutants (Fig. 7 B, C). Because Otop1 was downregulated in the inner ear of Raldh $3^{-/-}$ mutants, we performed additional ISH to compare its normal expression pattern with that of Raldh3 in wild-type mice. We found that the Otop1 expression pattern primarily overlaps with the Raldh3 expression pattern in the E18.5 inner ear (Fig. $7 A, B$ ). Moreover, we performed combined Raldh3 ISH and antineurofilament immunostaining, which showed that Raldh 3 is selectively expressed in the maculae, whereas anti-neurofilament immunostaining labels innervations that extend up to the sensory region of the maculae (Fig. $7 E, F$ ). We compared the developing innervation in the macula sacculi of a wild type (Fig. $7 G$ ) and Raldh $3^{-/-}$mutant (Fig. $7 H$ ) by anti-neurofilament staining. No recognizable difference in the fiber density was detected between the mutant and control.

\section{Discussion}

\section{RA and inner ear development}

The inner ear represents a primary target for RA action that, when altered, can lead to congenital deafness and balance disorders in humans (Lammer et al., 1985). Vitamin A deficiency (VAD) in rodent models results in a variety of developmental malformations known as the VAD syndrome, whereas intake of excess RA during pregnancy results in malformations referred to as RA embryopathy, which has been reported to affect ear development (Morris, 1972; Romand, 2003). Administration of excess RA during inner ear embryogenesis in the chick and rat generated specific phenotypes associated with the vestibular system (Choo et al., 1998; Coluccia et al., 2008).

Loss-of-function mutations of Raldh genes, which encode RA synthesizing enzymes, have revealed various organ phenotypes (for review, see Niederreither and Dollé, 2008; Duester, 2008; Rhinn and Dollé, 2012). Here our investigations of embryos and adult mice with single Raldh1, Raldh3, or compound Raldh1; Raldh3 null mutations revealed that, despite expression of both genes in the developing utricle and saccule (Romand et al., 2004, 2006), when Raldh 1 is inactivated and only one Raldh 3 allele is

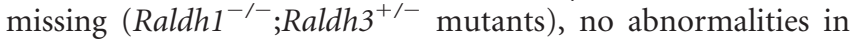
the vestibular organs are observed (Table 1). However, inactivation of the two Raldh3 alleles leads to vestibular functional defects (Figs. 1, 2) and organ dysmorphogenesis (Figs. 5, 6). From the various behavioral tests, it appears that both otolithic and semicircular canal-derived responses are affected (Hardisty-Hughes et al., 2010). The putative origin and functional consequences of the main structural alterations in the vestibular organs are discussed below.

\section{Canal malformation and related behaviors}

The smaller size of the vestibular canals in Raldh3 mutants is likely to be a determinant of circling behavior. When vestibular receptors are affected, circling behavior is usually specific to the 
Table 1. Morphological phenotypes of mice used in this study

\begin{tabular}{|c|c|c|c|c|c|c|c|}
\hline Genotype & Age & Utricle otoconial membrane & Utricle otoconia & Saccule otoconial membrane & Saccule otoconia & Cristae & Comments \\
\hline Raldh1 $^{-1-}$ (53), first ear & 10 weeks & + & + & + & + & + & Separation \\
\hline Raldh $1^{-1-}(53)$, second ear & 10 weeks & + & + & + & + & + & Separation \\
\hline Raldh3 ${ }^{-/-}$(161), EM & E14.5 & - & - & - & - & - & No separation \\
\hline Raldh $3^{+/+}(165)$ & E14.5 & - & - & - & - & - & No separation \\
\hline Raldh $3^{+/-}$(167), EM & E14.5 & - & - & - & - & - & No separation \\
\hline Raldh3 ${ }^{-1-}$ (228) & E14.5 & - & - & - & - & - & No separation \\
\hline Raldh $3^{+1+}(229)$ & E14.5 & - & - & - & - & + & Separation \\
\hline Raldh $3^{+/+}(200)$ & E18.5 & + & + & + & + & + & Separation \\
\hline Raldh $3^{-1-}$ (205) & E18.5 & + & - & + & - & + & No separation \\
\hline Raldh3 $^{-1-}(213)$ & E18.5 & + & Some otoconia & + & - & + & No separation \\
\hline Raldh3 ${ }^{-1-}$ (222), first ear & E18.5 & + & Some otoconia & + & - & + & No separation \\
\hline Raldh3 $3^{-1-}(222)$, second ear & E18.5 & + & Some otoconia & + & Some otoconia & + & No separation \\
\hline Raldh $^{+/+}(223)$ & E18.5 & + & + & + & + & + & Separation \\
\hline Raldh3 $3^{+/-}(384)$, EM & E18.5 & + & + & + & + & + & Separation \\
\hline Raldh $3^{-1-}$ (385), EM & E18.5 & + & - & + & - & + & No separation \\
\hline Raldh1 ${ }^{-1-}$, Raldh $^{+/+}(24), \mathrm{EM}$ & E18.5 & + & + & + & + & + & Separation \\
\hline Raldh1 $^{-1-}$, Raldh $3^{+/-}(28), \mathrm{EM}$ & E18.5 & + & + & + & + & + & Separation \\
\hline Raldh $1^{+1+}$, Raldh $3^{-1-}(29)$, first ear, EM & E18.5 & + & Some otoconia & + & Some otoconia & + & No separation \\
\hline Raldh $1^{+/+}$, Raldh3 $3^{-1-}(29)$, second ear & E18.5 & + & - & + & - & + & No separation \\
\hline Raldh $1^{-1-}$, Raldh3 ${ }^{-1-}$ (22), EM & E18.5 & + & - & + & - & + & No separation \\
\hline Raldh1 $^{-1-}$, Raldh3 ${ }^{+/-}(31)$ & P10 & + & - & + & - & + & Separation \\
\hline Raldh1 ${ }^{-1-}$, Raldh $^{+/+}$(32), EM & P10 & + & + & + & + & + & Separation \\
\hline Raldh1 ${ }^{-I-}$, Raldh $^{+1-}(43)$ & P10 & + & + & + & + & + & Separation \\
\hline Raldh $1^{+/+}$, Raldh $3^{+/+}$(47), EM & P10 & + & + & + & + & + & Separation \\
\hline Raldh ${ }^{+/+}$, Raldh $3^{-/-}(50)$, first ear & P10 & + & One giant & + & - & + & Separation \\
\hline Raldh $1^{+1+}$, Raldh $3^{-1-}(50)$, second ear & $\mathrm{P} 10$ & + & - & + & - & + & Separation \\
\hline Raldh ${ }^{+/-}$, Raldh $3^{+/-}$(52) & P10 & + & + & + & + & + & Separation \\
\hline Raldh1 $^{-1-}$, Raldh3 ${ }^{-1-}$ (1941), EM & 8 weeks & + & - & + & - & + & No separation \\
\hline Raldh1 ${ }^{-1-}$, Raldh3 ${ }^{-1-}$ (1942), EM & 8 weeks & + & - & + & - & + & No separation \\
\hline Raldh1 ${ }^{+/+}$, Raldh3 $3^{+-}$(1944) & 8 weeks & + & + & + & + & + & Separation \\
\hline Raldh1 ${ }^{+/-}$, Raldh3 $3^{+/-}$(1949) & 8 weeks & + & + & + & + & + & Separation \\
\hline Raldh1 ${ }^{+/+}$, Raldh3 ${ }^{+/-}$(1915), EM & 4.5 months & + & + & + & + & + & Separation \\
\hline Raldh1 ${ }^{+/+}$, Raldh $^{-1-}$ (1918), EM & 4.5 months & + & Some otoconia & + & - & + & No separation \\
\hline Raldh1 ${ }^{-1-}$,Raldh3 $3^{-1-}$ (1916) & 4.5 months & + & - & + & - & + & No separation \\
\hline Raldh1 ${ }^{-1-}$, Raldh3 ${ }^{-1-}$ (1917) & 4.5 months & + & - & + & - & + & No separation \\
\hline Raldh1 ${ }^{-1-}$,Raldh3 ${ }^{+/+}$(1952) & 6 months & + & + & + & + & + & Separation \\
\hline Raldh1 ${ }^{-1-}$,Raldh3 ${ }^{+1-}$ (1934) & 6 months & + & + & + & + & + & Separation \\
\hline 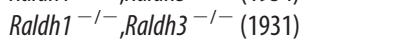 & 6 months & + & - & + & - & + & No separation \\
\hline
\end{tabular}

The utricular and saccular phenotypes observed in various Raldh1 and Raldh3 genotypes (mouse numbers in parentheses) are summarized. + and - signs indicate the presence or absence of anatomical structures. The analysis was performed on a single Raldh $1^{-1-}$ mutant at 10 weeks, on several (unrescued) Raldh $3^{-1-}$ mutants at E14.5 and E18.5 and on compound (Raldh1;Raldh3) mutants at E18.5 and postnatal stages (the latter after maternal RA rescue). Analysis was performed by both observation of serial semithin sections and, for some samples, transmission electron microscopy (EM). The two main features observed in the vestibular organs of Raldh3 ${ }^{-1-}$ mutants (whether RA rescued or not) is the absence of a membranous separation between the utricle and the saccule (No separation) and the lack of otoconia. Double mutants with one or two Raldh1-null alleles and a single Raldh3-null allele all showed otoconia.
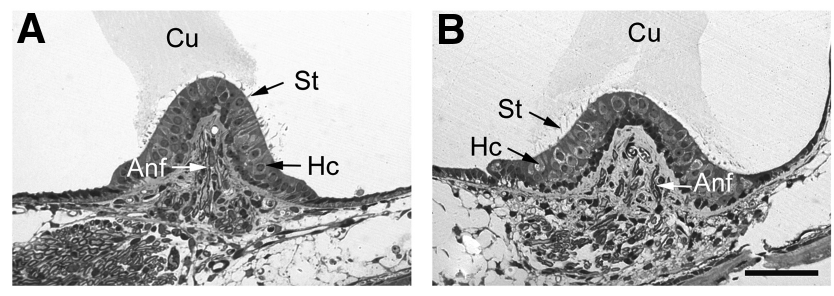

Figure 4. Light microscopic observation of the lateral cristae from 10-d-old mice. $A$, Raldh $3^{+/+}$control; $\boldsymbol{B}$, Raldh $3^{-/-}$mutant. Both cristae appear normal with their cupulae (Cu) and sensory epithelia with hair cells $(\mathrm{Hc})$ topped with stereocilia (St) and innervated by afferent nerve fibers (Anf). Scale bar, $50 \mu \mathrm{m}$.

canal and not otolithic deficiencies (Sun et al., 2001; Cryns et al., 2004; see discussion in Beraneck et al., 2012). However, circling behavior can also originate from CNS dysfunction, for example, attributable to cerebral asymmetry, without a defect in the peripheral vestibular system (Löscher, 2010). In rodents, circling is often associated with an imbalance in the forebrain dopamine system (Willis and Kennedy, 2004; Schirmer et al., 2007). Raldh3 is expressed in the developing striatum (McCaffery and Dräger,
1994), whereas Raldh1 is present in both developing and adult nigrostriatal dopaminergic neurons (Li et al., 2000). However, the circling behavior is not observed in mice carrying a null mutation for $R A R \beta$, a key receptor mediating RA signaling in the developing and adult striatum (W. Krezel, M. Rataj, and P. Dollé, unpublished data). Thus, this would argue against the idea that the locomotor abnormalities observed in Raldh $^{-1-}$ and Raldh $1^{-/-} ;$Raldh $3^{+/-}$mutant mice could be derived from alterations in the midbrain nigrostriatal system.

The smaller size of the vestibular canals in Raldh $3^{-/-}$mice presumably causes biomechanical constraints that correlate with the reduced aVOR responses found in these mutants (Fig. 2D-F). In particular, we observed a reduction in the canal time constant, as expected if the thinner canal mechanically reduces the transduction of the head rotation. The absence of otolith inputs could further impact the efficiency of the VOR. Andreescu et al. (2005) suggested that, in otoconia-deficient mice, the absence of otolith inputs could lead to a reduction of the aVOR, particularly at low frequencies. Although we do not exclude that this is the case in Raldh $3^{-/-}$mutants, the reduction of the VOR was also observed in response to stronger stimulation. The Raldh $3^{-/-}$mutation 


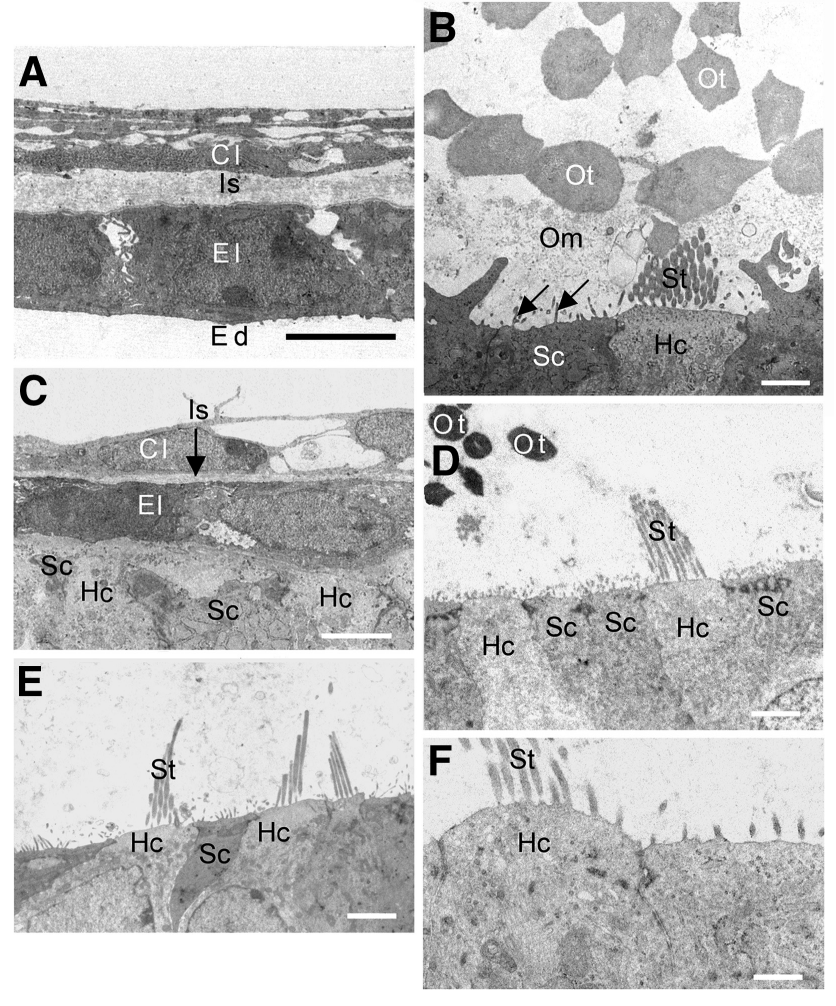

Figure 5. Electron microscopic analysis of the utricle and saccule in Raldh3 mutant mice. $\boldsymbol{A}$, Detail of the membrane lining the saccule (membrane limitans) in a control (wild-type) adult mouse. This membrane comprises an epithelial cell layer (EI) and a connective cell layer (CI) separated by an intercellular substance (Is). Ed, Endolymphatic space. $\boldsymbol{B}$, Apical region of the macula sacculi in a 10-d-old wild-type mouse, showing a hair cell (Hc) topped by stereocilia (St) and a supporting cell $(\mathrm{Sc})$ with numerous microvilli (arrows). Above these cells, the otoconial membrane $(0 \mathrm{~m})$ is covered by several otoconia (Ot). C, Apical region of the macula sacculi in a 10-d-old Raldh $1^{+/+} ;$;Raldh $3^{-/-}$mutant covered by a membrane limitans. D, Apical regions of hair cells $(\mathrm{Hc})$ and supporting cells $(\mathrm{Sc})$ from the macula sacculi of an E18.5 wild-type embryo. A hair cell is topped by stereocilia (St), above which otoconia $(0 t)$ are visible. $E$, Two hair cells $(\mathrm{Hc})$ topped with stereocilia (St) are separated by one supporting cell (Sc) from the macula utriculi of a E18.5 Raldh $1^{+/+} ;$Raldh $3^{-/-}$mutant. No otoconia are present. $\boldsymbol{F}$, E18.5 Raldh $3^{-1-}$ mouse. In this mutant, the membrane limitans has not collapsed over the macula sacculi, and stereocilia (St) are visible on the surface of the hair cell (Hc). Scale bars: $\boldsymbol{A}, \boldsymbol{C}, 5 \mu \mathrm{m} ; \boldsymbol{B}, 2 \mu \mathrm{m} ; \boldsymbol{D}, \boldsymbol{E}, 3 \mu \mathrm{m}$; $\boldsymbol{F}, 1.5 \mu \mathrm{m}$.

could also interfere with more discrete aspects of vestibular hair cell function, for instance, it could interfere with expression of specific ion channel proteins (Bao et al., 2003; Hotchkiss et al., 2005; Eugène et al., 2007). Finally, these observations do not preclude that other cellular mechanisms such as changes in the electrophysiological properties of vestibular afferents or changes in the projections onto central nuclei might be in play for the reduction of the aVOR in Raldh 3 mutants.

\section{Otolith-related abnormalities and molecular origin of the dysmorphogenesis}

The absence or reduction in the number of otoconia in the otolithic organs of Raldh $3^{-/-}$mutants may also contribute to the behavioral and functional deficits found in these mice. First, mutations affecting the otolith organs usually generate a tilting of the head (Jones et al., 1999, 2004, 2005; Hughes et al., 2006; Lundberg et al., 2006; Beraneck et al., 2012), which was also observed in Raldh $3^{-1-}$ mutant mice. Second, the off-vertical axis tests revealed a complete absence of utricular modulation (Fig. 2B), which demonstrates a major impairment of the MOR. Otolith impairment affects the functionally appropriate assembly of ves-
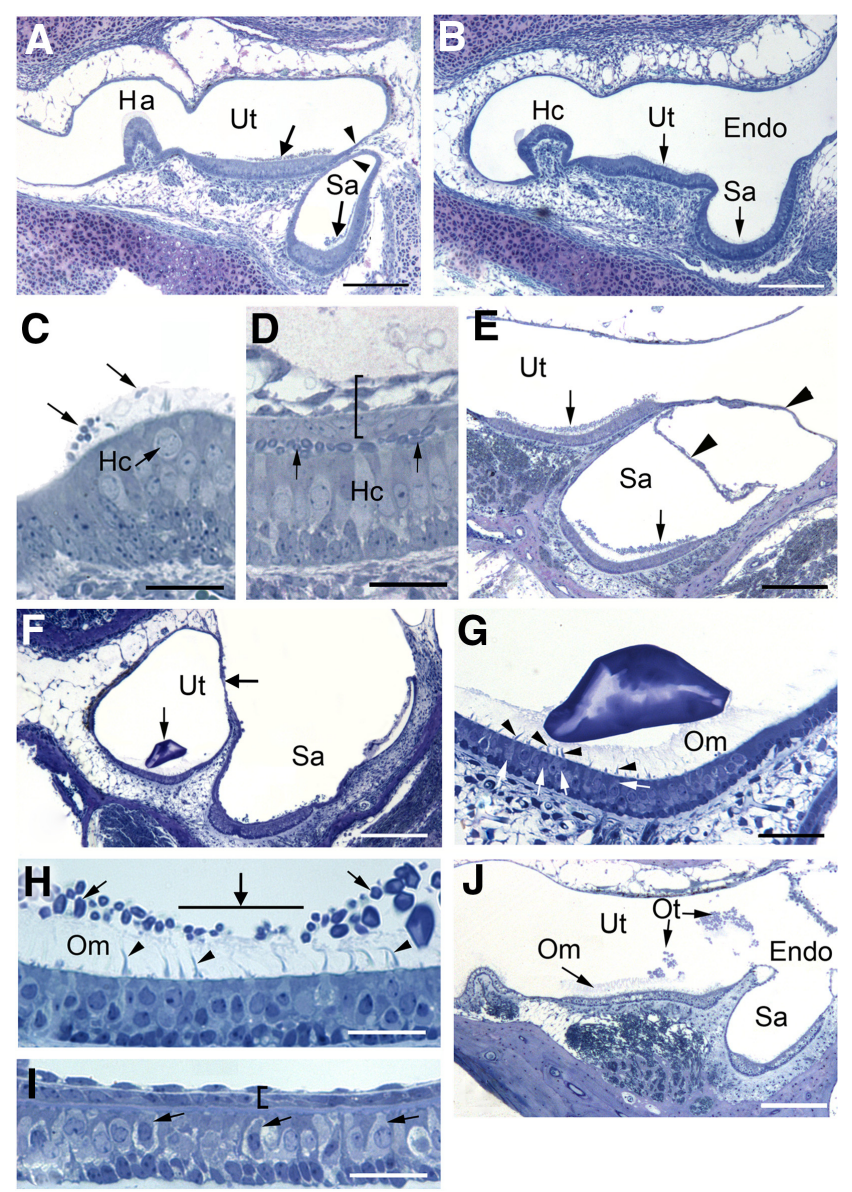

Figure 6. L Light microscopic analysis of the saccular and utricular maculae in Raldh1;Raldh3 mutant mice before and after birth. $\boldsymbol{A}$, Raldh $1^{-/-} ;$Raldh $3^{+/+}$mutant at E18.5. Otoconia (large arrows) are visible at the level of the macula utriculi (Ut) and macula sacculi (Sa). Arrow-

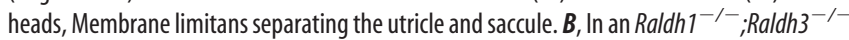
E18.5 mutant, no otoconia are present over the otoconial membranes of the utricle (Ut) and saccule (Sa) (arrows). C, In another Raldh $1^{-1-}$; Raldh $3^{-1-}$ mutant, a small number of otoconia are observed at the lateral edge of the macula utriculi (small arrows). Hc, Hair cell. $\boldsymbol{D}$, In the saccule of the same mutant, the membrane limitans that should normally overlie the nonsensory region, here directly lies over the apical region of the macula sacculi (bracket). Some otoconia (arrows) are trapped between the collapsed membrane limitans and the sensory hair cells (Hc). E, A 10-d-old Raldh $1^{+/+} ;$;Raldh $3^{+/-}$mutant presents a normal morphology with otoconia in the utricle and the saccule (arrows) and the presence of membranes limitans (arrowheads). $\boldsymbol{F}$, In an Raldh $1^{+/+} ;$Raldh $3^{-/-}$mutant, a single otoconium resembling a fish otolith is seen in the utricle (Ut). $\mathbf{G}$, High-magnification view of the single giant otoconium on top of the otoconial membrane $(0 \mathrm{~m})$. White arrows, Hair cells; arrowheads, stereocilia. $\boldsymbol{H}$, High-magnification view of the surface of the macula sacculi at the level of the striolar region in a 10 -d-old Raldh $1^{+/+} ;$Raldh $3^{+/-}$mouse. Hair cells with their stereocilia (arrowheads) are embedded in the otoconial membrane $(0 \mathrm{~m})$ topped by numerous otoconia (arrows), except at the level of the striolar region (large arrow). $I$, Surface of the macula sacculi of an $R a l d h 1^{+/+}$; Raldh $3^{-1-}$ mutant, topped by a collapsed membrane limitans (bracket). Hair cells are present (arrows) but without visible stereocilia. J, Utricle and saccule of a 4.5-month-old Raldh $1^{+/+}$; Raldh $3^{-1-}$ mutant. Some otoconia (Ot) are seen in a restricted region of the utricle $(\mathrm{Ut})$, more or less detached from the otoconial membrane $(0 \mathrm{~m})$. No otoconia are observed in the saccule. Endo, Common endolymphatic space; Ha, horizontal crista ampullaris. Scale bars: $\boldsymbol{A}, \boldsymbol{B}, \boldsymbol{E}, \boldsymbol{F}, \boldsymbol{J}$, $200 \mu \mathrm{m} ; \boldsymbol{C}, \boldsymbol{D}, \boldsymbol{H}, \boldsymbol{I}, 30 \mu \mathrm{m} ; \boldsymbol{G}, 50 \mu \mathrm{m}$.

tibular signaling pathways and the interaction between semicircular canal and otolith signals (Andreescu et al., 2005; Angelaki and Cullen, 2008). One of us (M.B.) reported recently in another model of otoconia-deficient mice that the absence of otolith inputs results in ocular instabilities and major deficiencies in the tuning of the aVOR (Beraneck et al., 2012). The presence of a nystagmus in Raldh $3^{-1-}$ mutants and the abnormal spatial tun- 

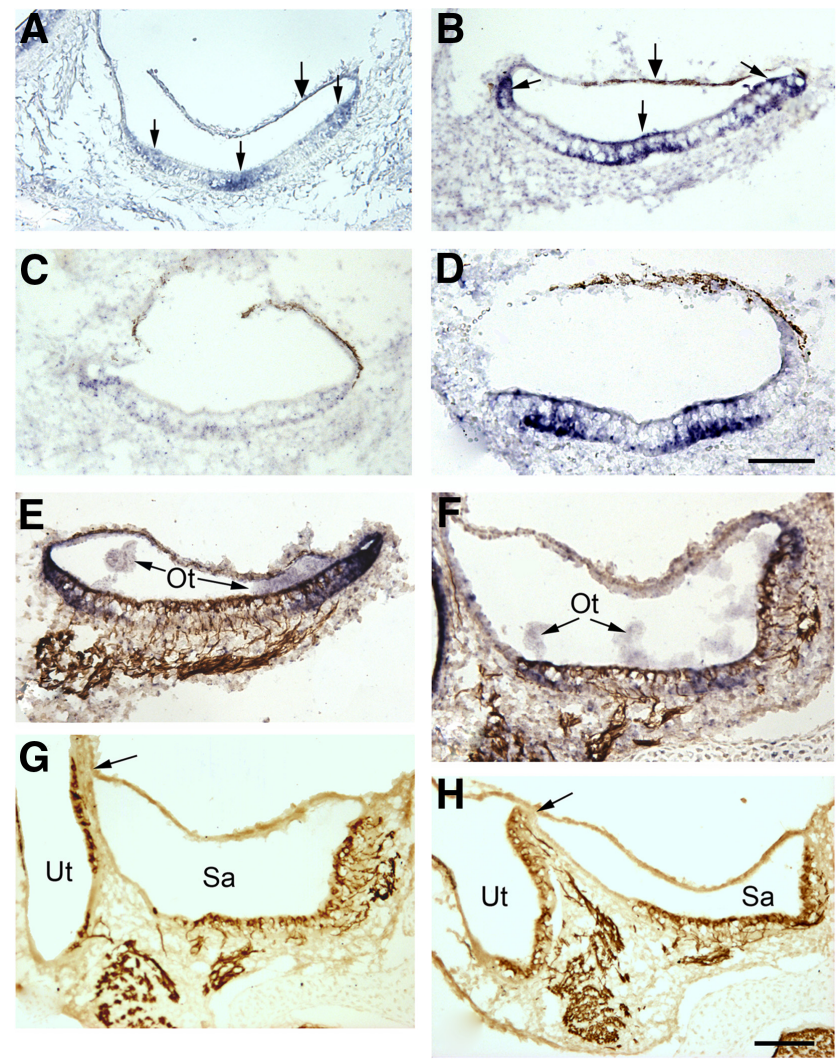

Figure 7. $\quad \boldsymbol{A}-\boldsymbol{D}, \mathrm{ISH}$ analysis of wild-type and Raldh $3^{-/-}$mice at E18.5. A, Raldh3 expression in wild type is mainly restricted to three regions of the macula utriculi (arrows). Large arrow, Membrane limitans lining the utricle. $\boldsymbol{B}$, Otop1 expression in the utricle of a wild-type embryo mimics the Raldh3 signal observed in $\boldsymbol{A}$. C, Otop 1 expression is absent in a littermate

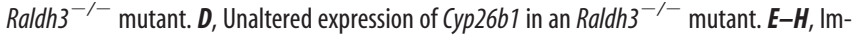
munohistochemical neurofilament staining in the utricle and saccule of wild-type and Raldh $3^{-/-}$mice at E18.5. E, F, Double Raldh3 ISH labeling (blue) and neurofilament immunostaining (brown) on sections of the utricle $(\boldsymbol{A})$ and saccule $(\boldsymbol{B})$ of a wild-type mouse. 0t, 0 toconia. $\boldsymbol{G}, \boldsymbol{H}$, Neurofilament immunostaining in the utricle and saccule of a wild-type mouse $(\boldsymbol{C})$ compared with the same organs at an equivalent level of section in an Raldh $3^{-1-}$ mutant (D). In the mutant, the separation between the saccule and utricle is barely visible (arrows). Scale bars, $100 \mu \mathrm{m}$.

ing of the aVOR are additional evidence of the role played by the otolith organs in the homeostasis of gaze stabilization.

Another striking phenotype in Raldh $3^{-1-}$ mice is the presence of a fused utriculo-saccular cavity. At present, the mechanisms responsible for this abnormality and for the smaller size of the vestibular canals, and their putative causal link, remain unknown. The fused utriculo-saccular cavity is reminiscent of the phenotype seen in $H m x$-null mice, in which the mutants exhibited a similar endolymphatic space fused between the utricle and saccule, along with mild dysmorphogenesis of the lateral vestibular canal (Wang et al., 1998). In the Epistatic circler mutant, aberrant expression of Bmp4 was shown to contribute to the semicircular abnormalities and circling behavior (Cryns et al., 2004; Chang et al., 2008). Spurred by these results, we analyzed expression of Bmp4 and Hmx2 in Raldh $3^{-/-}$mutants but did not find any differences in their expression patterns when compared with those in wild-type mice. To clearly understand the mechanisms underlying the defects in the Raldh $3^{-/-}$mice, additional investigation is required to screen additional candidate genes whose dysregulation could lead to otolith organs and semicircular canals dysmorphogenesis (Jones et al., 2005; Adams et al., 2007; Chatterjee et al., 2010; Kurima et al., 2011).

\section{Otop1 may be a potential target gene regulated by RA during otoconia formation}

Given the strong otolithic abnormalities, we searched for genes that could be downregulated by Raldh 3 ablation and investigated the expression of several genes whose deletion in mutant mice generated an absence or modifications of otoconia or otoconial membrane, namely Tecta, Oc90, Otop1, Noxo3, Noxo1, Otog, and Otoa. Of these genes tested, only Otop1 was downregulated in Raldh $3^{-/-}$mice (Fig. 5). Interestingly, the phenotype related to gravity receptors for Raldh $3^{-/-}$mice in this study strongly resembles the Otop $1^{-/-}$phenotype described by Ornitz et al., (1998), which showed selective loss of otoconia in the utricle and the saccule. Video oculography results also demonstrate functional similarities between Otop 1 and Raldh3 mutants (Beraneck et al., 2012). Another similarity between these two mutants lies in normal appearance of sensory hair cells and supporting cells in the saccule and the utricle. Moreover, a giant otoconia was observed in one of our Raldh3-null mice, as was also seen in Otop1 mutants (Ornitz et al., 1998). However, Otop $1^{-/-}$mice do not seem to recapitulate the entire Raldh $3^{-/-}$vestibular phenotype, because they were not reported to have reduced semicircular canals or collapsed membrane limitans. These observations suggest that Otop 1 may be a potential target gene regulated by RA during otoconia formation. If this is the case, the action of RA on Otop 1 should be mediated by direct binding of RA receptors (RAR $\alpha$, $\operatorname{RAR} \beta$, and $\operatorname{RAR} \gamma$ ), all of which are expressed in the developing murine vestibular organs (Romand, 2003). RA deficiency might then lead to otoconia agenesis through suppression of Otop 1 expression responsible for the tilted phenotype described in mutant mice (Ornitz et al., 1998; Hurle et al., 2003; Jones et al., 2004; Besson et al., 2005). Otop1 was shown to act as a sensor for extracellular calcium concentration increasing intracellular calcium levels during otoconia mineralization (Kim et al., 2010). In the case of impaired RA signaling occurring in Raldh $3^{-/-}$mice, the selective downregulation of Otop1 would affect its function in concentrating $\mathrm{Ca}^{2+}$ in supporting cells, thereby impeding the nucleation and growth of otoconia.

In conclusion, our findings reveal an essential role for the RA synthesizing enzyme Raldh3 in proper morphological development of the otolith organs and semicircular canals, the vestibular end organs that detect linear acceleration and angular rotation, respectively. In the absence of Raldh3, the overall size and thickness of the semicircular canals was significantly reduced and the synthesis of otoconia was severely impaired in the otolith organ attributable at least in part to downregulation of Otop1. These morphological anomalies in Raldh3 mutant mice resulted in deficiencies in vestibular functions, as shown by postural and locomotor deficits, as well as vestibulo-ocular impairments. These results stress the importance of endogenous RA in the control of inner ear development and function.

\section{Notes}

Supplemental material for this article is available at http://lbgi.igbmc. fr/Raldh3.avi. Behavior of an Raldh $3^{+/+}$control mouse versus an Raldh $3^{-1-}$ mutant mouse. The circling behavior of the former was recorded in the mouse's cage. This was followed by a test of motor coordination and balance on a beam of $1 \mathrm{~m}$ length. The third test was the righting contact reflex performed in a Plexiglas cylinder, which was followed by the swim test in a Plexiglas tank, $1 \mathrm{~m}$ in length. This material has not been peer reviewed.

\section{References}

Adams ME, Hurd EA, Beyer LA, Swiderski DL, Raphael Y, Martin DM (2007) Defects in vestibular sensory epithelia and innervation in mice 
with loss of Chd7 function: implications for human CHARGE syndrome. J Comp Neurol 504:519-532. CrossRef Medline

Adrian ED (1943) Discharges from vestibular receptors in the cat. J Physiol 101:389-407. Medline

Andreescu CE, De Ruiter MM, De Zeeuw CI, De Jeu MT (2005) Otolith deprivation induces optokinetic compensation. J Neurophysiol 94:34873496. CrossRef Medline

Angelaki DE, Cullen KE (2008) Vestibular system: the many facets of a multimodal sense. Annu Rev Neurosci 31:125-150. CrossRef

Angelaki DE, Hess BJ, Suzuki J (1995) Differential processing of semicircular canal signals in the vestibulo-ocular reflex. J Neurosci 15:7201-7216. Medline

Anniko M (1980) Development of otoconia. Am J Otolaryngol 1:400-410. CrossRef Medline

Bao H, Wong WH, Goldberg JM, Eatock RA (2003) Voltage-gated calcium channel currents in type I and type II hair cells isolated from the rat crista. J Neurophysiol 90:155-164. CrossRef Medline

Beraneck M, Cullen KE (2007) Activity of vestibular nuclei neurons during vestibular and optokinetic stimulation in the alert mouse. J Neurophysiol 98:1549-1565. CrossRef Medline

Beraneck M, Bojados M, Le Séac'h A, Jamon M, Vidal PP (2012) Ontogeny of mouse vestibulo-ocular reflex following genetic or environmental alteration of gravity sensing. PLoS One 7:e40414. CrossRef Medline

Besson V, Nalesso V, Herpin A, Bizot JC, Messaddeq N, Romand R, Puech A, Blanquet V, Hérault Y (2005) Training and aging modulate the loss-ofbalance phenotype observed in a new ENU-induced allele of Otopetrin1. Biol Cell 97:787-798. CrossRef Medline

Calabrese DR, Hullar TE (2006) Planar relationships of the semicircular canals in two strains of mice. J Assoc Res Otolaryngol 7:151-159. CrossRef Medline

Carter RJ, Morton J, Dunnett SB (2001) Motor coordination and balance in rodents. Curr Protoc Neurosci Chapter 8:Unit 8.12. CrossRef Medline

Chatterjee S, Kraus P, Lufkin T (2010) A symphony of inner ear developmental control genes. BMC Genetics 11:68. CrossRef Medline

Chevallier A, Mialot A, Petit JM, Fernandez-Salguero P, Barouki R, Coumoul X, Beraneck M (2013) Oculomotor deficits in Aryl hydrocarbon receptor null mouse. PLoS One 8:e53520. CrossRef Medline

Choo D, Sanne JL, Wu DK (1998) The differential sensitivities of inner ear structures to retinoic acid during development. Dev Biol 204:136-150. CrossRef Medline

Chotteau-Lelièvre A, Dollé P, Gofflot F (2006) Expression analysis of murine genes using in situ hybridization with radioactive and nonradioactively labeled RNA probes. Methods Mol Biol 326:61-87. CrossRef Medline

Coluccia A, Borracci P, Belfiore D, Renna G, Giustino A, Carratù MR (2008) Effects of early gestational all-trans retinoic acid treatment on motor skills: a longitudinal study in the offspring of Sprague-Dawley rats. Neurotoxicology 29:1107-1113. CrossRef Medline

Cryns K, van Alphen AM, van Spaendonck MP, van de Heyning PH, Timmermans JP, de Zeeuw CI, van Camp G (2004) Circling behavior in the $\mathrm{Ecl}$ mouse is caused by lateral semicircular canal defects. J Comp Neurol 468:587-595. CrossRef Medline

Delacroix L, Moutier E, Altobelli G, Legras S, Poch O, Choukrallah MA, Bertin I, Jost B, Davidson I (2010) Cell-specific interaction of retinoic acid receptors with target genes in mouse embryonic fibroblasts and embryonic stem cells. Mol Cell Biol 30:231-244. CrossRef Medline

Diez-Roux G, Banfi S, Sultan M, Geffers L, Anand S, Rozado D, Magen A, Canidio E, Pagani M, Peluso I, Lin-Marq N, Koch M, Bilio M, Cantiello I, Verde R, De Masi C, Bianchi SA, Cicchini J, Perroud E, Mehmeti S, et al. (2011) A high-resolution anatomical atlas of the transcriptome in the mouse embryo. PLoS Biol 9:e1000582. CrossRef Medline

Duester G (2000) Families of retinoid dehydrogenases regulating vitamin A function: production of visual pigment and retinoic acid. Eur J Biochem 267:4315-4324. CrossRef Medline

Duester G (2008) Retinoic acid synthesis and signaling during early organogenesis. Cell 134:921-931. CrossRef Medline

Duester G, Mic FA, Molotkov A (2003) Cytosolic retinoid dehydrogenases govern ubiquitous metabolism of retinol to retinaldehyde followed by tissue-specific metabolism to retinoic acid. Chem Biol Interact 143-144: 201-210. CrossRef

Dupé V, Matt N, Garnier JM, Chambon P, Mark M, Ghyselinck NB (2003) A newborn lethal defect due to inactivation of retinaldehyde dehydroge- nase type 3 is prevented by maternal retinoic acid treatment. Proc Natl Acad Sci U S A 100:14036-14041. CrossRef Medline

Erway LC, Purichia NA, Netzler ER, D’Amore MA, Esses D, Levine M (1986) Genes, manganese, and zinc in formation of otoconia: labeling, recovery, and maternal effects. Scan Electron Microsc (Pt 4):1681-1694. Medline

Eugène D, Deforges S, Guimont F, Idoux E, Vidal PP, Moore LE, Vibert N (2007) Developmental regulation of the membrane properties of central vestibular neurons by sensory vestibular information in the mouse. J Physiol 583:923-943. CrossRef Medline

Fernández C, Goldberg JM (1976) Physiology of peripheral neurons innervating otolith organs of the squirrel monkey. III. Response dynamics. J Neurophysiol 39:996-1008. Medline

Fernández C, Goldberg JM, Abend WK (1972) Response to static tilts of peripheral neurons innervating otolith organs of the squirrel monkey. J Neurophysiol 35:978-987. Medline

Goldberg JM, Fernandez C (1971) Physiology of peripheral neurons innervating semicircular canals of the squirrel monkey. I. Resting discharge and response to constant angular accelerations. J Neurophysiol 34:635-660. Medline

Hardisty-Hughes RE, Parker A, Brown SD (2010) A hearing and vestibular phenotyping pipeline to identify mouse mutants with hearing impairment. Nat Protoc 5:177-190. CrossRef Medline

Hotchkiss K, Harvey M, Pacheco M, Sokolowski B (2005) Ion channel proteins in mouse and human vestibular tissue. Otolaryngol Head Neck Surg 132:916-923. CrossRef Medline

Hughes I, Thalmann I, Thalmann R, Ornitz DM (2006) Mixing model systems: using zebrafish and mouse inner ear mutants and other organ systems to unravel the mystery of otoconial development. Brain Res 1091: 58-74. CrossRef Medline

Hurle B, Ignatova E, Massironi SM, Mashimo T, Rios X, Thalmann I, Thalmann R, Ornitz DM (2003) Non-syndromic vestibular disorder with otoconial agenesis in tilted/mergulhador mice caused by mutations in otopetrin 1. Hum Mol Genet 12:777-789. CrossRef Medline

Iurato S (1967) Submicroscopic structure of the inner ear. Oxford, UK: Pergamon.

Jones SM, Erway LC, Bergstrom RA, Schimenti JC, Jones TA (1999) Vestibular responses to linear acceleration are absent in otoconia-deficient C57BL/6JEi-het mice. Hear Res 135:56-60. CrossRef Medline

Jones SM, Erway LC, Johnson KR, Yu H, Jones TA (2004) Gravity receptor function in mice with graded otoconial deficiencies. Hear Res 191:34-40. CrossRef Medline

Jones SM, Kenneth R, Johnson KR, Yu H, Erway LC, Alagramam KN, Pollak $\mathrm{N}$, Jones TA (2005) A quantitative survey of gravity receptor function in mutant mouse strains. J Assoc Res Otolaryng 6:297-310.

Kim E, Hyrc KL, Speck J, Lundberg YW, Salles FT, Kachar B, Goldberg MP, Warchol ME, Ornitz DM (2010) Regulation of cellular calcium in vestibular supporting cells by Otopetrin 1. J Neurophysiol 104:3439-3450. CrossRef Medline

Kurima K, Hertzano R, Gavrilova O, Monahan K, Shpargel KB, Nadaraja G, Kawashima Y, Lee KY, Ito T, Higashi Y, Eisenman DJ, Strome SE, Griffith AJ (2011) A noncoding point mutation of Zeb1 causes multiple developmental malformations and obesity in Twirler mice. PLoS Genet 7:e1002307. CrossRef Medline

Lammer EJ, Chen DT, Hoar RM, Agnish ND, Benke PJ, Braun JT, Curry CJ, Fernhoff PM, Grix AW Jr, Lott IT, Tichard JM, Sun SC (1985) Retinoic acid embryopathy. New Eng J Med 313:837-841. CrossRef Medline

Li H, Wagner E, McCaffery P, Smith D, Andreadis A, Dräger UC (2000) A retinoic acid synthesizing enzyme in ventral retina and telencephalon of the embryonic mouse. Mech Dev 95:283-289. CrossRef Medline

Lim DJ (1984) The development and structure of the otoconia. In: Ultrastructure atlas of the inner ear (Friedmann I, Ballantyne J, eds), pp 245269. London: Butterworth-Heinemann.

Lindeman HH (1969) Studies on the morphology of the sensory regions of the vestibular apparatus. Adv Anat Embryol Cell Biol 42:1-110.

Löscher W (2010) Abnormal circling behavior in rat mutants and its relevance to model specific brain dysfunctions. Neurosci Biobehav Rev 34: 31-49. CrossRef Medline

Lundberg YW, Zhao X, Yamoah EN (2006) Assembly of the otoconia complex to the macular sensory epithelium of the vestibule. Brain Res 1091: 47-57. CrossRef Medline

Lyon MF (1955) The development of the otoliths of the mouse. J Embryol Exp Morphol 3:213-229. 
Mandillo S, Tucci V, Hölter SM, Meziane H, Banchaabouchi MA, Kallnik M, Lad HV, Nolan PM, Ouagazzal AM, Coghill EL, Gale K, Golini E, Jacquot S, Krezel W, Parker A, Riet F, Schneider I, Marazziti D, Auwerx J, Brown SD, et al. (2008) Reliability, robustness, and reproducibility in mouse behavioral phenotyping: a cross-laboratory study. Physiol Genomics 34: 243-255. CrossRef Medline

Matt N, Dupé V, Garnier JM, Dennefeld C, Chambon P, Mark M, Ghyselinck NB (2005) Retinoic acid-dependent eye morphogenesis is orchestrated by neural crest cells. Development 132:4789-4800. CrossRef Medline

McCaffery P, Dräger UC (1994) High levels of a retinoic acid-generating dehydrogenase in the meso-telencephalic dopamine system. Proc Natl Acad Sci U S A 91:7772-7776. CrossRef Medline

Morris GM (1972) Morphogenesis of the malformations induced in rat embryos by maternal hypervitaminosis. Am J Anat 113:241-250.

Niederreither K, Dollé P (2008) Retinoic acid in development: towards an integrated view. Nat Rev Genet 9:541-553. CrossRef Medline

Niederreither K, Subbarayan V, Dollé P, Chambon P (1999) Embryonic retinoic acid synthesis is essential for early mouse post-implantation development. Nat Genet 4:444-448. CrossRef Medline

Niederreither K, Vermot J, Schuhbaur B, Chambon P, Dollé P (2000) Retinoic acid synthesis and hindbrain patterning in the mouse embryo. Development 127:75-85. Medline

Niederreither K, Fraulob V, Garnier JM, Chambon P, Dollé P (2002) Differential expression of retinoic acid-synthesizing (RALDH) enzymes during fetal development and organ differentiation in the mouse. Mech Dev 110:165-171. CrossRef Medline

Oommen BS, Stahl JS (2008) Eye orientation during static tilts and its relationship to spontaneous head pitch in the laboratory mouse. Brain Res 1193:57-66. CrossRef Medline

Ornitz DM, Bohne BA, Thalmann I, Harding GW, Thalmann R (1998) Otoconial agenesis in tilted mutant mice. Hear Res 122:60-70. CrossRef Medline

Rhinn M, Dollé P (2012) Retinoic acid signalling during development. Development 139:843-858. CrossRef Medline

Romand R (2003) The role of retinoic acid during inner ear development. In: Development of auditory and vestibular systems-3. Molecular development of the inner ear. Current topics in developmental biology, Vol 57
(Romand R, Varela-Nieto eds), pp 262-291. Amsterdam: Elsevier Academic.

Romand R, Niederreither K, Abu-Abed S, Petkovich M, Fraulob V, Hashino E, Dolle' P (2004) Complementary expression patterns of retinoic acidsynthesizing and -metabolizing enzymes in pre-natal mouse inner ear structures. Genes Expr Patterns 4:123-133. CrossRef Medline

Romand R, Kondo T, Fraulob V, Petkovich M, Dollé P, Hashino E (2006) Dynamic expression of retinoic acid-synthesizing and -metabolizing enzymes in the developing mouse inner ear. J Comp Neurol 496:643-654. CrossRef Medline

Ross SA, McCaffery PJ, Drager UC, De Luca LM (2000) Retinoids in embryonal development. Physiol Rev 80:1021-1054. Medline

Schirmer M, Lessenich A, Lindemann S, Löscher W (2007) Marked differences in response to dopamine receptor antagonism in two rat mutants, ci2 and ci3, with lateralized rotational behavior. Behav Brain Res 180: 218-225. CrossRef Medline

Stahl JS (2004) Using eye movements to assess brain function in mice. Vision Res 44:3401-3410. CrossRef Medline

Stahl JS, Oommen BS (2008) Eye hyperdeviation in mouse cerebellar mutants is comparable to the gravity-dependent component of human downbeat nystagmus. Prog Brain Res 171:503-508. CrossRef Medline

Sun JC, van Alphen AM, Wagenaar M, Huygen P, Hoogenraad CC, Hasson T, Koekkoek SK, Bohne BA, De Zeeuw CI (2001) Origin of vestibular dysfunction in Usher syndrome type 1B. Neurobiol Dis 8:69-77. CrossRef Medline

van Alphen B, Winkelman BH, Frens MA (2010) Three-dimensional optokinetic eye movements in the C57BL/6 J mouse. Invest Ophthalmol Vis Sci 51:623-630. CrossRef Medline

Wagner E, Luo T, Dräger UC (2002) Retinoic acid synthesis in the postnatal mouse brain marks distinct developmental stages and functional systems. Cereb Cortex 12:1244-1253. CrossRef Medline

Wang W, Van De Water T, Lufkin T (1998) Inner ear and maternal reproductive defects in mice lacking the $\mathrm{Hmx} 3$ homeobox gene. Development 125:621-634. Medline

Willis GL, Kennedy GA (2004) The implementation of acute versus chronic animal models for treatment discovery in Parkinson's disease. Rev Neurosci 15:75-87. Medline 